\title{
PENGARUH KEPEMIMPINAN, KOMPENSASI FINANSIAL DAN KOMITMEN ORGANISASIONAL TERHADAP KINERJA PEGAWAI DENGAN DISIPLIN KERJA SEBAGAI MEDIASI (STUDI PADA KANTOR BKKBN PROVINSI JAWA TENGAH)
}

\author{
SOEGIHARTONO
}

Fakultas Ekonomi Universitas Semarang

Diterima: November 2018. Disetujui: Desember 2018. Dipublikasikan: Januari 2019

\begin{abstract}
This research was conducted at the Office of the Central Java Province BKKBN and aims to test and analyze whether there is influence of leadership, financial compensation and organizational commitment to the performance of employees with work discipline as mediation. The sample in this study is all employees of BKKBN Office of Central Java Province with the number of 115 employees who made as respondents.The sampling technique in this study used a saturated sample or census method. And the method of data analysis used in this research is path analysis.The result of analysis shows that leadership has positive and significant effect to employee performance, financial compensation has positive and significant effect to employee performance, organizational commitment has positive and significant effect to employee performance, leadership has positive and significant effect to work discipline, financial compensation has positive and significant influence on work discipline, organizational commitment have a positive and significant effect on work discipline, work discipline has positive and significant effect to employee performance, leadership has positive and significant effect to employee performance with work discipline mediation and organizational commitment have positive and significant influence to employee performance with work discipline mediation.
\end{abstract}

Keywords: leadership, financial compensation, organizational commitment, work discipline and employee performance.

\begin{abstract}
ABSTRAK
Penelitian ini dilakukan pada Kantor BKKBN Provinsi Jawa Tengah dan bertujuan untuk menguji dan menganalisis apakah terdapat pengaruh kepemimpinan, kompensasi finansial dan komitmen organisasi terhadap kinerja karyawan dengan mediasi disiplin kerja. Sampel dalam penelitian ini adalah seluruh pegawai Kantor BKKBN Provinsi Jawa Tengah dengan jumlah 115 karyawan yang dijadikan responden. Teknik pengambilan sampel dalam penelitian ini menggunakan sampel jenuh atau metode sensus. Dan metode analisis data yang digunakan dalam penelitian ini adalah analisis jalur. Hasil analisis menunjukkan bahwa kepemimpinan berpengaruh positif dan signifikan terhadap kinerja karyawan, kompensasi finansial berpengaruh positif dan signifikan terhadap kinerja karyawan, komitmen organisasi berpengaruh positif dan signifikan terhadap karyawan kinerja, kepemimpinan berpengaruh positif dan signifikan terhadap disiplin kerja, kompensasi finansial berpengaruh positif dan signifikan terhadap disiplin kerja, komitmen organisasi berpengaruh positif dan signifikan terhadap disiplin kerja, disiplin kerja berpengaruh positif dan signifikan terhadap kinerja karyawan, kepemimpinan berpengaruh positif dan signifikan terhadap disiplin kerja. pengaruh signifikan terhadap kinerja karyawan dengan mediasi disiplin kerja dan komitmen organisasi berpengaruh positif dan signifikan terhadap kinerja karyawan dengan mediasi disiplin kerja.
\end{abstract}

Kata kunci: kepemimpinan, kompensasi finansial, komitmen organisasi, disiplin kerja dan kinerja karyawan 


\section{Pendahuluan}

Badan Kependudukan dan Keluarga Berencana Nasional (disingkat BKKBN) adalah Lembaga Pemerintah Nonkementerian yang berada di bawah dan bertanggung jawab kepada Presiden melalui Menteri Kesehatan. BKKBN mempunyai tugas melaksanakan tugas pemerintahan di bidang pengendalian penduduk dan penyelenggaraan keluarga berencana. Badan Kependudukan dan Keluarga Berencana Nasional Provinsi Jawa Tengah (BKKBN Jateng), merupakan Lembaga Pemerintah Non Departemen Indonesia yang bertugas melaksanakan tugas pemerintahan di bidang kependudukan dan keluarga berencana di provinsi jateng. Yang memiliki fungsi antara lain untuk fasilitasi dan pembinaan terhadap kegiatan instansi pemerintah, swasta, LSOM dan masyarakat dibidang Keluarga Berencana dan Keluarga Sejahtera. dan juga penyelenggaraan pembinaan dan pelayanan administrasi umum dibidang perencanaan umum, ketatausahaan, organisasi dan tatalaksana, kepegawaian, persandian, keuangan, kearsipan, hukum, perlengkapan dan rumah tangga. Agar organisasi dapat mencapai suatu tujuannya, diperlukan disiplin kerja pegawai yang baik.

Dalam hal ini, terdapat masalah yang terjadi dalam organisasi tentang disiplin kerja pegawai. Berdasarkan data absensi, berikut data mengenai tingkat absensipegawai kantor BKKBN Provinsi Jawa Tengah:

Tabel 1.

\section{Rekapitulasi Absensi PegawaiKantor BKKBN Provinsi Jawa Tengah}

Periode Tahun 2016

\begin{tabular}{|l|c|c|c|}
\hline Bulan & $\begin{array}{c}\text { Jumlah } \\
\text { Karyawan } \\
\text { (Orang) }\end{array}$ & $\begin{array}{c}\text { Jumlah } \\
\text { Efektivitas } \\
\text { Bekerja }\end{array}$ & $\begin{array}{c}\text { Tingkat } \\
\text { Absensi } \\
\text { (Orang) }\end{array}$ \\
\hline Januari & 125 & 2500 & 94 \\
\hline Februari & 124 & 2480 & 127 \\
\hline Maret & 122 & 2562 & 111 \\
\hline April & 120 & 2520 & 81 \\
\hline Mei & 120 & 2400 & 82 \\
\hline Juni & 117 & 2691 & 78 \\
\hline Juli & 114 & 1824 & 50 \\
\hline
\end{tabular}




\begin{tabular}{l|l|c|c|c|}
\hline Agustus & 116 & 2668 & 63 \\
\hline September & 116 & 2436 & 141 \\
\hline Oktober & 115 & 2415 & 111 \\
\hline November & 114 & 2508 & 66 \\
\cline { 2 - 5 } Desember & 114 & 2280 & 174 \\
\hline
\end{tabular}

Dari tabel 1. diatas menunjukan tingkat absensi pegawai kantor BKKBN Provinsi Jawa Tengah pada periode Januari 2016 sampai dengan Desember 2016 berfluktuasi. Dapat dilihat dari absensi karyawan pada bulan Januari yang mencapai 3,76\%, Februari 5,12\%, Maret 4,33\%, April 3,21\%, Mei 3,42\%, Juni 2,90\%, Juli 2,74\%, Agustus 2,36\%, September 5,79\%, Oktober 4,60\%, November 2,63\%dan Desember 7,63\%. Dari tabel tersebut terlihat tingkat absensi paling besar terjadi pada bulan Desember.

Pada dasarnya yang menjadi ukuran baik dan buruknya kinerja pegawai kantor BKKBN Provinsi Jawa Tengah adalah tercapainya target organisasi. Namun pada faktanya ada indikator yang tidak mencapai target kinerja. Dapat ditunjukan dalam tabel berikut:

Tabel 2.

Pencapaian Kinerja Program Kependudukan, Keluarga Berencana dan Pembangunan Keluarga (KKBPK) Periode Tahun 2016

\begin{tabular}{|c|l|c|c|c|}
\hline NO & \multicolumn{1}{|c|}{ INDIKATOR KONTRAK KINERJA } & $\begin{array}{c}\text { SASARAN } \\
\mathbf{2 0 1 6}\end{array}$ & $\begin{array}{c}\text { CAPAIAN } \\
\mathbf{2 0 1 6}\end{array}$ & \% \\
\hline \multicolumn{1}{|c|}{ SASARAN STRATEGIS } & 63,8 & 61,26 & 96,02 \\
\hline 1 & Angka Prevalensi Penggunaan Kontrasepsi (CPR) & 15,66 & 9,5 & 60,66 \\
\hline 2 & $\begin{array}{l}\text { Persentase Kebutuhan ber KB yang tidak terpenuhi } \\
\text { unmetneed) }\end{array}$ & 38,8 & 28,01 & 72,19 \\
\hline 3 & Presentase Peserta KB Baru MKJP & 25,8 & 27,63 & 107,09 \\
\hline 4 & Presentase Peserta KB Aktif MKJP & \multicolumn{3}{|c|}{} \\
\hline \multicolumn{1}{|c|}{ SASARAN PROGRAM } & 36,2 & 5,90 & 16,30 \\
\hline 1 & Persentase Kesertaan KB Pria (PA) MOP dan Kondom & 53,9 & 51,20 & 94,99 \\
\hline 2 & Indeks pengetahuan remaja tentang KRR & 10 & $9.56 \%$ & 95,6 \\
\hline 3 & $\begin{array}{l}\text { Persentase sasaran yang mendapatkan promosi dan konseling } \\
\text { Kesehatan Reproduksi }\end{array}$ & 44 & 35,90 & 81,59 \\
\hline 4 & Persentase masyarakat yang mengetahui isu kependudukan & \multicolumn{2}{|c|}{} \\
\hline
\end{tabular}


Tabel 3.

\section{Data Pra SurveyKantor BKKBN Provinsi Jawa Tengah}

\begin{tabular}{|c|c|c|c|}
\hline NO & ALASAN & $\mathbf{F}$ & $\%$ \\
\hline 1 & $\begin{array}{l}\text { Kurangnya kedisiplinan } \\
\text { pegawai }\end{array}$ & 8 & 26.7 \\
\hline 2 & $\begin{array}{l}\text { Kurangnya perhatian dari } \\
\text { pimpinan }\end{array}$ & 6 & 20 \\
\hline 3 & $\begin{array}{l}\text { Lingkungan kerja yang } \\
\text { kurang kondusif }\end{array}$ & 2 & 6,7 \\
\hline 4 & $\begin{array}{l}\text { Dampak tunjangan kinerja } \\
\text { terhadap pekerjaan }\end{array}$ & 7 & 23.3 \\
\hline 5 & Minimnya tegur, salam, sapa & 1 & 3,3 \\
\hline 6 & $\begin{array}{l}\text { Kurangnya efektifitas } \\
\text { bekerja }\end{array}$ & 6 & 20 \\
\hline & TOTAL & 30 & 100 \\
\hline
\end{tabular}

Berdasarkan tabel 3. diatas menunjukan hasil pra kuesioner mengenai hal-hal yang perlu diperhatikan di Kantor BKKBN Provinsi Jawa Tengah. Dapat dilihat dari hasil pra kuesioner pada alasan kurangnya kedisiplinan pegawai sebesar 26,7\% yang dapat diartikan bahwa disiplin kerja pegawai pada Kantor BKKBN Provinsi Jawa Tengah masih rendah. Selain itu pada alasan kurangnya perhatian dari pimpinan sebesar $20 \%$, yang dapat diartikan bahwa kepemimpinan pada Kantor BKKBN Provinsi Jawa Tengah masih ada yang harus dibenahi. Pada alasan dampak tunjangan kinerja terhadap pekerjaan sebesar 23,3\% yang dapat diartikan bahwa kompensasi finansial sangat berperan penting dalam tercapainya target organisasi, tetapi pada faktanya ada indikator yang tidak mencapai target sasaran. Pada alasan kurangnya efektifitas bekerja sebesar $20 \%$, yang dapat diartikan bahwa komitmen organisasional pegawai pada Kantor BKKBN Provinsi Jawa Tengah masih rendah.

Didukung oleh hasil wawancara terhadap seorang staff bagian kepegawaian di kantor BKKBN Provinsi Jawa Tengah, dimana seorang staff mengatakan bahwa jam kerja di kantor BKKBN Provinsi Jawa Tengah pada hari Senin sampai Kamis dimulai dari pukul 07.30 - 16.00 dan hari Jum'at dimulai dari pukul 07.30 - 13.30, tetapi karena minimnya teguran dari pimpinan sehingga banyak pegawai yang datang terlambat dan banyak juga pegawai yang pulang lebih cepat dari jam kerja yang sudah ditentukan. Kemudian di kantor BKKBN Provinsi Jawa Tengah banyak ditemukan pegawai yang tidak terlalu memperhatikan standar operasional prosedur (SOP) dalam bekerja seperti tidak memakai 
sepatu dan lebih memilih memakai sandal jepit pada saat jam kerja. Dan didalam waktu efektif kerja, sering digunakan untuk istirahat.

\section{Rumusan Masalah}

1. Apakah terdapat pengaruh kepemimpinan terhadap kinerja pegawai?

2. Apakah terdapat pengaruh kompensasi finansial terhadap kinerja pegawai?

3. Apakah terdapat pengaruh komitmen organisasional terhadap kinerja pegawai?

4. Apakah terdapat pengaruh kepemimpinan terhadap disiplin kerja?

5. Apakah terdapat pengaruh kompensasi finansial terhadap disiplin kerja?

6. Apakah terdapat pengaruh komitmen organisasional terhadap disiplin kerja?

7. Apakah terdapat pengaruh disiplin kerja terhadap kinerja pegawai?

8. Apakah terdapat pengaruh kepemimpinan terhadap kinerja pegawai dengan disiplin kerja sebagai mediasi?

9. Apakah terdapat pengaruh komitmen organisasional terhadap kinerja pegawai dengan disiplin kerja sebagai mediasi?

\section{Tujuan Penelitian}

1. Untuk mengetahuipengaruh kepemimpinan terhadap kinerja pegawai.

2. Untuk mengetahuipengaruh kompensasi finansial terhadap kinerja pegawai.

3. Untuk mengetahuipengaruh komitmen organisasional terhadap kinerja pegawai.

4. Untuk mengetahuipengaruh kepemimpinan terhadap disiplin kerja.

5. Untuk mengetahuipengaruh kompensasi finansial terhadap disiplin kerja.

6. Untuk mengetahuipengaruh komitmen organisasional terhadap disiplin kerja.

7. Untuk mengetahuipengaruh disiplin kerja terhadap kinerja pegawai.

8. Untuk mengetahuipengaruh kepemimpinan terhadap kinerja pegawai dengan disiplin kerja sebagai mediasi.

9. Untuk mengetahuipengaruh komitmen organisasional terhadap kinerja pegawai dengan disiplin kerja sebagai mediasi. 


\section{Landasan Teori}

\section{Kinerja Pegawai}

Menurut Henry Simamora mengemukakan pendapatnya mengenai kinerja pegawai dalam bukunya: Manajemen Sumber Daya Manusia (1995:325), sebagi berikut: “Kinerja pegawai adalah tingkat dimana para karyawan/pegawai mencapai persyaratan-persyaratan pekerjaan".

Hasibuan (2012:94) kinerja pegawai merupakan suatu hasil kerja yang dicapai seseorang dalam melaksanakan tugas-tugas yang diberikan kepadanya, yang didasarkan atas kecakapan pengalaman dan kesungguhan serta waktu. Selain itu, menurut Sunyoto (2012:18) menyatakan bahwa kinerja pegawai adalah sesuatu hasil kerja yang dicapai seseorang dalam melaksanakan menyelesaikan pekerjaan yang dibebankan kepadanya.

Simmamora(2004:314) menyatakan,kinerja dapat dipengaruhi oleh faktor-faktor sebagai berikut:

a. Faktor individual yang terdiri darikemampuan dan faktor demografi.

b. Faktor psikologis yang terdiri dari sikap, motivasi, persepsi, personality dan pembelajaran.

c. Faktor organisasi yang terdiri dari sumber daya, kepemimpinan, penghargaan, strukturdan job design.

Menurut Gibson (2003), ada tiga faktor yang berpengaruh terhadap kinerja, yaitu sebagai berikut:

a. Faktor individu, meliputi kemampuan, keterampilan, latar belakang keluarga pengalaman kerja, tingkat sosial dan demografi seseorang.

b. Faktor psikologis, meliputi persepsi, peran, sikap, kepribadian, motivasi, lingkungan kerja, komitmen dan kepuasan kerja.

c. Faktor Organisasi, meliputi stuktur organisasi,desain, pekerjaan, kepemimpinan dan sistem penghargaan (reward system).

Siagian (2002) menyatakan bahwa, kinerja pegawai dipengaruhi beberapa faktor, yaitu: kompensasi, lingkungan kerja, budaya organisasi, kepemimpinan, motivasi kerja, disiplin kerja, kepuasan kerja, komunikasi dan faktor faktor lainnya. 


\section{Disiplin Kerja}

Menurut Mangkunegara (2013:129) disiplin kerja diartikan sebagai pelaksanaan manajemen untuk memperteguh pedoman-pedoman organisasi. Kadang-kadang, perilaku pekerja dalam organisasi menjadi sangat mengganggu sehingga berdampak dengan kinerja yang menurun. Disiplin kerja yang baik dan berkualitas merupakan kunci utama keberhasilan suatu organisasi/instansi dimana apabila hal tersebut diterapkan dengan baik dan benar maka keinginan dan tujuan suatu organiasi/instansi dapat terwujud (Shelviana, 2015).

Pengertian disiplin kerja merupakan salah satu fungsi operatif yang terpenting dan tidak dapat diabaikan karena sebagai bagian dari fungsi pemeliharaan karyawan, dan bilamana semakin baik disiplin kerja karyawan, makin tinggi prestasi kerja yang dapat dicapainya. Untuk memperjelas hal ini, disiplin kerja memiliki sejumlah indikator (Muchadarsyah Sinungan, 1995) yakni:

1. Absensi; yakni pendataan kehadiran pegawai yang sekaligus merupakan alat untuk melihat sejauh mana pegawai itu mematuhi peraturan yang berlaku dalam perusahaan.

2. Sikap dan Perilaku; yakni tingkat penyesuaian diri seorang pegawai dalam melaksanakan semua tugas-tugas dari atasannya.

3. Tanggung Jawab; yakni hasil atau konsekuensi seorang pegawai atas tugas-tugas yang diserahkan kepadanya.

\section{a. Kepemimpinan}

Menurut Moejiono (2002) pengertian kepemimpinan adalah kemampuan dalam memberikan pengaruh satu arah, karena pemimpin mungkin memiliki beberapa kualitas tertentu yang membuatnya berbeda dengan pengikutnya. Kepemimpinan merupakan suatu ilmu yang mengkaji secara komprehensif tentang bagaimana mengarahkan, mempengaruhi, dan mengawasi orang lain untuk mengerjakan tugas sesuai perintah yang direncanakan (Fahmi, 2016:105). Keberhasilan seseorang pemimpin tergantung kepada kemampuan untuk mempengaruhi. Dengan kata lain kepemimpinan diartikan sebagai kemampuan seseorang untuk mempengaruhi orang lain, melalui komunikasi yang langsung maupun tidak langsung dengan maksud menggerakkan orang-orang tersebut 
agar dengan penuh pengertian, kesadaran dan senang hati bersedia mengikuti kehendak pemimpin itu (Nugraheni dkk, 2016).

\section{b. Kompensasi Finansial}

Menurut Sastrohadiwiryo (2003:181) kompensasi finansial adalah Imbalan jasa atau balas jasa yang diberikan oleh perusahaan kepada para tenaga kerja karena tenaga kerja tersebut telah memberikan sumbangan tenaga dan pikiran demi kemajuan perusahaan guna mencapai tujuan yang telah ditetapkan. Menurut Sunyoto (2012:31) bahwa kompensasi finansial adalah sesuatu yang diterima oleh karyawan dalam bentuk seperti gaji, upah, bonus, premi, tunjangan hari raya, tunjangan hari tua, pengobatan atau jaminan kesehatan, asuransi dan lain-lain yang sejenis yang dibayarkan oleh organisasi. Hasibuan (dalam Agung, 2013) menyatakan bahwa kepentingan organisasi dengan pemberian kompensasi yaitu untuk mendapatkan imbalan prestasi kerja yang lebih besar dari pegawai. Sedangkan kepentingan pegawai atas kompensasi yang diterima yaitu dapat memenuhi kebutuhan dan keinginanya dan menjadi keamanan ekonomi rumah tangganya.

\section{c. Komitmen Organisasional}

Pengertian tentang komitmen organisasi oleh Alwi (2001) dijelaskan bahwa komitmen diartikan sebagai sikap karyawan untuk tetap berada dalam organisasi dan terlibat dalam upaya-upaya mencapai misi, nilai-nilai dan tujuan perusahaan. Lebih lanjut dijelaskan komitmen adalah bentuk loyalitas yang lebih konkrit yang dapat dilihat dari sejauh mana karyawan mencurahkan perhatian, gagasan, dan tanggung jawabnya dalam upaya mencapai tujuan perusahaan. Komitmen organisasi adalah suatu keadaan dimana seseorang pegawai memihak organisasi tertentu serta tujuan-tujuan dan keinginannya untuk mempertahankan keanggotaan dalam organisasi tersebut (Shobirin dkk, 2016).Komitmen terhadap organisasi artinya lebih dari sekedar keanggotaan formal, karena meliputi sikap menyukai organisasi dan kesediaan untuk mengusahakan tingkat upaya yang lebih tinggi bagi kepentingan organisasinya demi pencapaian tujuan. Berdasarkan definisi ini, dalam komitmen organisasi tercakup unsur loyalitas terhadap organisasi, keterlibatan dalam pekerjaan, dan identifikasi terhadap nilai-nilai dan tujuan organisasi (Triyaningsih, 2014). 


\section{Metode Penelitian}

Dalam penelitian ini penulis melakukan penelitian pada Kantor BKKBN Provinsi Jawa Tengah. Populasi dalam penelitian ini adalah seluruh pegawai pada Kantor BKKBN Provinsi Jawa Tengah sebanyak 115 pegawai.Dataini didapatkan berdasarkan data dari Kantor BKKBN Provinsi Jawa Tengah.

Dalam penelitian ini, karena jumlah populasinya sedikit (terbatas) sehingga tidak memungkinkan untuk menggunakan sampel, sehingga peneliti mengambil jumlah sampel sama dengan jumlah populasi. Sampel dalam penelitian ini adalah seluruh pegawai Badan Kependudukandan Keluarga Berencana Nasional Provinsi Jawa Tengah sebanyak 115 orang pegawai.

Skala yang digunakan dalam penyusunan kuesioner atau angket ini adalah skala interval:

$$
\begin{aligned}
& 1 \text { = Sangat Tidak Setuju } \\
& 2=\text { Tidak Setuju } \\
& 3=\text { Netral } \\
& 4=\text { Setuju } \\
& 5=\text { Sangat Setuju }
\end{aligned}
$$

Skala LIKERT dikatakan ordinal bila pernyataan Sangat Setuju mempunyai tingkat atau preferensi yang "lebih tinggi" dari Setuju, dan "lebih tinggi" dari "Netral" (Ghozali, 2013:146). Metode analisis data dalam penelitian ini menggunakan analisis jalur (path analysis).

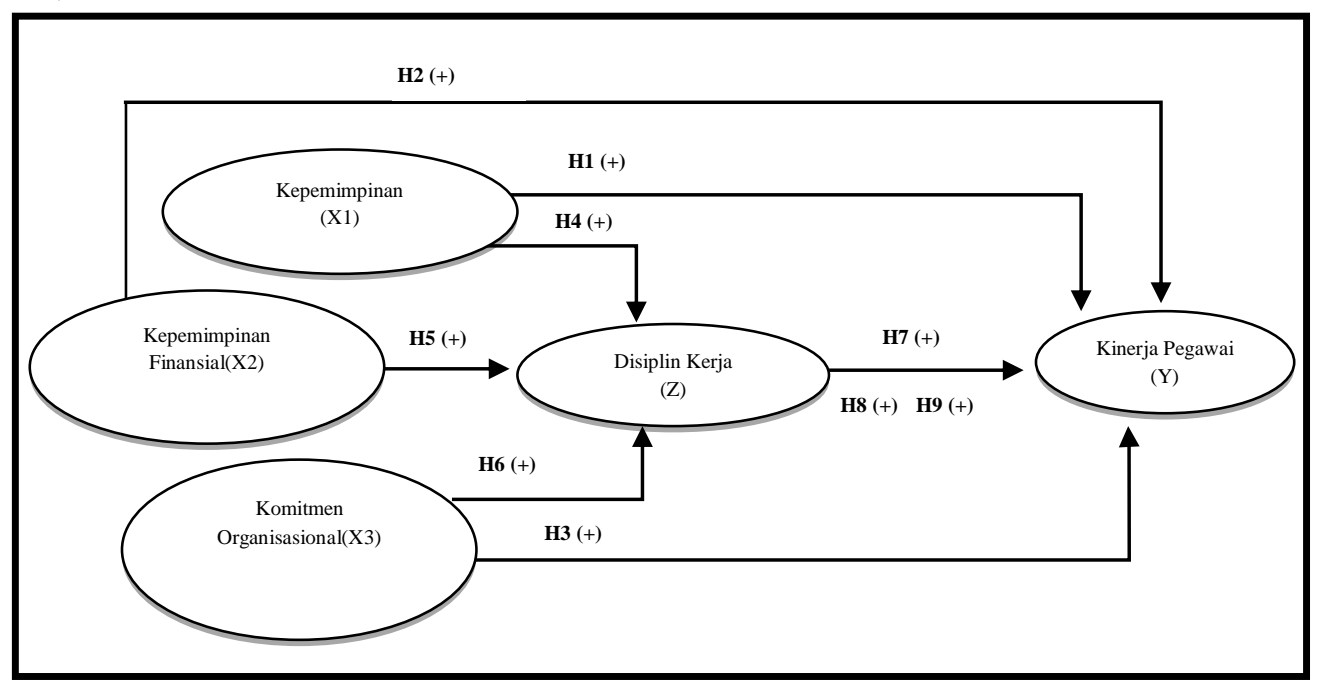

Gambar 1.Model Penelitian 


\section{Hasil dan Pembahasan}

\section{Uji Validitas dan Reliabilitas}

Tabel 4.

Hasil Uji Validitas dan Reabilitas

\begin{tabular}{|c|c|c|}
\hline Indikator & $\begin{array}{c}\text { Cronbach } \\
\text { Alpha }\end{array}$ & Ket. \\
\hline Kinerja Pegawai & 0,749 & Valid dan Reliabel \\
\hline Disiplin Kerja & 0,797 & Valid dan Reliabel \\
\hline Kepemimpinan & 0,821 & Valid dan Reliabel \\
\hline Kompensasi Finansial & 0,807 & Valid dan Reliabel \\
\hline Komitmen Organisaional & 0,757 & Valid dan Reliabel \\
\hline
\end{tabular}

Sumber: Data primer yang diolah, 2017.

Suatu konstruk atau variabel dikatakan valid dan reliable jika memberikan nilai Cronbach Alpha lebih besar dari 0,70 (Ghozali, 2013:47). Berdasarkan pada tabel 4. Terlihat hasil uji validitas dan reliabilitas menunjukkan koefisien Cronbach's Alpha pada variable kinerja pegawai sebesar 0,749. Hal ini menunjukkan bahwa variable tersebut valid dan reliabel, dilihat dari koefisien Cronbach's Alpha yang nilainya lebih dari0,70 $(0,749>0,70)$. Koefisien Cronbach's Alpha pada variabel disiplin kerja sebesar 0,797. Hal ini menunjukkan bahwa variable tersebut valid dan reliabel, dilihat dari koefisien Cronbach's Alpha yang nilainya lebih dari 0,70 $(0,797>0,70)$. Koefisien Cronbach's Alpha pada variable kepemimpinan sebesar 0,821. Hal ini menunjukkan bahwa variable tersebut valid dan reliabel, dilihat dari koefisien Cronbach's Alpha yang nilainya lebih dari $0,70(0,821>0,70)$. Koefisien Cronbach's Alpha pada variabel kompensasi finansial sebesar 0,807. Hal ini menunjukkan bahwa variable tersebut valid dan reliabel, dilihat dari koefisien Cronbach's Alpha yang nilainya lebih dari 0,70 $(0,807>0,70)$. Koefisien Cronbach's Alpha pada variabel komitmen organisasional sebesar 0,757. Hal ini menunjukkan bahwa variable tersebut valid dan reliabel, dilihat dari koefisien Cronbach's Alpha yang nilainya lebih dari 0,70 $(0,757>0,70)$. 
Hasil uji reliabilitas menunjukkan bahwa untuk indikator-indikator dari seluruh poin dan total pertanyaan dari lingkungan kerja, kepemimpinan dan kedisiplinan karyawan bahwa Cronbach Alpha lebih besar dari nilai Cronbach Alpha yang ditentukanya itu lebih besar $(>0,70)$. Dapat disimpulkan bahwa keseluruhan variable tersebut adalah reliabel.

\section{Uji Heteroskedastisitas}

Uji heteroskedastisitas bertujuan menguji apakah dalam model regresi terjadi ketidaksamaan variance dari residual satu pengamatan ke pengamatan yang lain. Oleh karena itu diperlukan analisis uji statistik yaitu uji glejser yaitu dengan meregres nilai absolute residual terhadap variable independen (Ghozali, 2013:143).

\section{Tabel 5.}

\section{Hasil Uji Heteroskedastisitas Kinerja Pegawai dengan Uji Glejser}

\begin{tabular}{|c|c|c|c|}
\hline \multicolumn{4}{|c|}{ Coefficients $^{\mathrm{a}}$} \\
\hline \multicolumn{2}{|c|}{ Model } & $\mathrm{t}$ & Sig. \\
\hline & (Constant) & .908 & .366 \\
\hline & Disiplin Kerja & -1.457 & .148 \\
\hline & Kepemimpinan & -1.340 & .183 \\
\hline & Kompensasi Finansial & 1.405 & .163 \\
\hline & Komitmen Organisasional & 1.824 & .071 \\
\hline \multicolumn{4}{|c|}{ a. Dependent Variable: Glejser_Kinerja_Pegawai } \\
\hline
\end{tabular}

Sumber: Data primer yang diolah, 2017.

Berdasarkan tabel 5. diatas, bahwa nilai signifikansi variabel disiplin kerja sebesar 0,148 . Variabel kepemimpinan sebesar 0,183. Variabel kompensasi finansial sebesar 0,163 dan variabel komitmen organisasional sebesar 0,073 yang semuanya lebih dari 0,05 $(0,148>0,05),(0,183>0,05),(0,163>0,05)$ dan $(0,073>0,05)$. Maka hasil yang diperoleh dapat disimpulkan bahwa model regresi tidak terdapat heteroskedastisitas.

\section{Tabel 6.}

\section{Hasil Uji Heteroskedastisitas Disiplin Kerja dengan Uji Glejser}

\begin{tabular}{|c|c|c|}
\hline \multicolumn{3}{|c|}{ Coefficients $^{\mathrm{a}}$} \\
\hline Model & $\overline{\mathrm{t}}$ & Sig. \\
\hline (Constant) & -.567 & .572 \\
\hline Kepemimpinan & .683 & .496 \\
\hline Kompensasi Finansial & 1.706 & .091 \\
\hline Komitmen Organisasional & -1.126 & .263 \\
\hline \multicolumn{3}{|c|}{ a. Dependent Variable: Glejser_Disiplin_Kerja } \\
\hline
\end{tabular}

Berdasarkan tabel 6. diatas, bahwa nilai signifikansi variabel kepemimpinan sebesar 0,496. Variabel kompensasi finansial sebesar 0,091 dan variabel komitmen organisasional sebesar 0,263 yang semuanya lebih dari $0,05(0,496>0,05),(0,091>0,05)$ 
dan $(0,263>0,05)$. Maka hasil yang diperoleh dapat disimpulkan bahwa model regresi tidak terdapat heteroskedastisitas.

Tabel7.

\section{Hasil Uji Analisis Jalur}

\section{Persamaan Regresi 1}

\begin{tabular}{|c|c|c|c|c|c|c|}
\hline \multicolumn{7}{|c|}{ Coefficients $^{\mathrm{a}}$} \\
\hline \multirow{2}{*}{\multicolumn{2}{|c|}{ Model }} & \multicolumn{2}{|c|}{$\begin{array}{c}\text { Unstandardized } \\
\text { Coefficients }\end{array}$} & \multirow{2}{*}{$\begin{array}{c}\text { Standardized } \\
\text { Coefficients }\end{array}$} & \multirow[t]{2}{*}{$\mathrm{t}$} & \multirow[t]{2}{*}{ Sig. } \\
\hline & & $\mathrm{B}$ & Std. Error & & & \\
\hline \multirow{5}{*}{1} & (Constant) & .686 & .836 & & .821 & .414 \\
\hline & Disiplin Kerja & 189 & .084 & .238 & 2.256 & .026 \\
\hline & Kepemimpinan & .202 & .084 & .257 & 2.422 & .017 \\
\hline & Kompensasi Finansial & .161 & .068 & .226 & 2.377 & .019 \\
\hline & Komitmen Organisasional & .180 & .088 & .208 & 2.060 & .042 \\
\hline
\end{tabular}

Sumber: Data primer yang diolah, 2017

Berdasarkan tabel 7.dapat diketahui bahwa hasil matematis regresi linear berganda dari persamaan regresi 1 (satu) adalah sebagai berikut:

$$
Y=0,686+0,189 Z+0,202 X_{1}+0,161 X_{2}+0,180 X_{3}+\varepsilon
$$

Dari tabel7. diatas menunjukkan bahwa keempat variabel independent yaitu disiplin kerja, kepemimpinan, kompensasi finansial dan komitmen organisasional yang dimasukkan ke dalam model regresi memiliki nilai signifikansi masing-masing yaitu disiplin kerjasebesar 0,026 kepemimpinan 0,017 kompensasi finansial 0,019 komitmen organisasional 0,042 .

Tabel 8.

Hasil Uji Analisis Jalur

Persamaan Regresi 2

\begin{tabular}{|c|c|c|c|c|c|}
\hline \multicolumn{6}{|c|}{ Coefficients $^{\mathrm{a}}$} \\
\hline \multirow[t]{2}{*}{ Model } & \multicolumn{2}{|c|}{$\begin{array}{c}\text { Unstandardized } \\
\text { Coefficients }\end{array}$} & \multirow{2}{*}{$\begin{array}{l}\begin{array}{r}\text { Standardized } \\
\text { Coefficients }\end{array} \\
\text { Beta }\end{array}$} & \multirow[t]{2}{*}{$\mathrm{t}$} & \multirow[t]{2}{*}{ Sig. } \\
\hline & $\mathrm{B}$ & Std. Error & & & \\
\hline (Constant) & .546 & .974 & & .561 & .576 \\
\hline Kepemimpinan & .462 & .086 & .468 & 5.346 & .000 \\
\hline Kompensasi Finansial & .174 & 077 & 195 & 2.255 & .026 \\
\hline Komitmen Organisasional & .301 & .098 & .277 & 3.079 & .003 \\
\hline
\end{tabular}

Sumber: Data primer yang diolah, 2017 
Berdasarkan tabel 8.dapat diketahui bahwa hasil matematis regresi linear berganda dari persamaan regresi 2 (dua) adalah sebagai berikut:

$$
Z=0,546+0,462 X_{1}+0,174 X_{2}+0,301 X_{3}+\varepsilon .
$$

Dari tabel 8. Diatas menunjukkan bahwa ketiga variabel independent yaitu kepemimpinan, kompensasi finansial dan komitmen organisasional yang dimasukkan kedalam model regresi memiliki nilai signifikansi masing-masing yaitu kepemimpinan 0,000 kompensasi finansial 0,026 komitmen organisasional 0,003.

Hasil analisis jalur menunjukkan bahwa Kepemimpinan dapat berpengaruh langsung terhadap Kinerja Pegawai dan dapat juga berpengaruh tidak langsung yaitu dari Kepemimpinan ke Disiplin Kerja (sebagai variabel mediasi) lalu ke Kinerja Pegawai. Besarnya pengaruh langsung adalah sebesar 0,202 sedangkan besarnya pengaruh tidak langsung harus dihitung dengan mengalikan koefisen tidak langsungnya yaitu P4 x P7 $(0,462 \times 0,189)=0,087$. Sedangkan total pengaruh Kepemimpinan terhadap Kinerja Pegawai yang dimediasi oleh Disiplin Kerja yaitu P1 + (P4 x P7) adalah sebagai berikut $0,202+(0,462 \times 0,189)=0,289$.

Dari hasil analisis jalur juga menunjukkan bahwa Komitmen Organisasional dapat berpengaruh langsung terhadap Kinerja Pegawai dan dapat juga berpengaruh tidak langsung yaitu dari Komitmen Organisasional ke Disiplin Kerja (sebagai variabel mediasi) lalu ke Kinerja Pegawai. Besarnya pengaruh langsung adalah sebesar 0,180 sedangkan besarnya pengaruh tidak langsung harus dihitung dengan mengalikan koefisen tidak langsungnya yaitu P6 x P7 $(0,301 \times 0,189)=0,057$. Sedangkan total pengaruh Kepemimpinan terhadap Kinerja Pegawai yang dimediasi oleh Disiplin Kerja yaitu P3 + $(\mathrm{P} 6 \times \mathrm{P} 7)$ adalah sebagai berikut $0,180+(0,301 \times 0,189)=0,237$.

Pengaruh mediasi yang ditunjukkan oleh perkalian koefisien (P4 x P7) dan (P6 x P7) yaitu sebesar 0,087 dan 0,057. Signifikan atau tidak, diuji dengan Sobel test sebagai berikut:

$$
\begin{aligned}
\mathrm{Sab} & =\sqrt{b^{2} S a^{2}+a^{2} S b^{2}+S a^{2} S b^{2}} \\
& =\sqrt{(0,189)^{2}(0,086)^{2}+(0,462)^{2}(0,084)^{2}+(0,086)^{2}(0,084)^{2}} \\
& =0,04269 .
\end{aligned}
$$




$$
\begin{aligned}
& \text { thitung } \quad=\frac{a b}{S a b} \\
& =\frac{(0,462)(0,189)}{0,04269} \\
& =2,0454 . \\
& \text { Sab } \quad \sqrt{b^{2} S a^{2}+a^{2} S b^{2}+S a^{2} S b^{2}} \\
& =\sqrt{(0,189)^{2}(0,098)^{2}+(0,301)^{2}(0,084)^{2}+(0,098)^{2}(0,084)^{2}} \\
& =0,03241 . \\
& =\frac{a b}{\mathrm{t}_{\text {hitung }}} \quad \\
& =\frac{(0,301)(0,189)}{0,03241} \\
& =1,7553 .
\end{aligned}
$$

Berdasarkan hasil Sobel test diatas, dapat diambil kesimpulan yaitu:

1. Untuk variabel Kepemimpinan, mendapat nilai $t_{\text {hitung }}$ sebesar 2,0454 lebih besar dari $\mathrm{t}_{\text {tabel }}$ dengan tingkat signifikansi 0,05 yaitu sebesar 1,6591, maka dapat disimpulkan bahwa koefisien mediasi 0,087 signifikan yang berarti ada pengaruh mediasi. Maka dapat disimpulkan bahwa Disiplin Kerja mampu memediasi hubungan antara Kepemimpinan dengan Kinerja Pegawai.

2. Untuk variabel Komitmen Organisasional, mendapat nilai thitung sebesar 1,7553 lebih besar dari $t_{\text {tabel }}$ dengan tingkat signifikansi 0,05 yaitu sebesar 1,6591, maka dapat disimpulkan bahwa koefisien mediasi 0,057 signifikan yang berarti ada pengaruh mediasi. Maka dapat disimpulkan bahwa Disiplin Kerja mampu memediasi hubungan antara Komitmen Organisasional dengan Kinerja Pegawai.

\section{Pembahasan Hasil Penelitian}

\section{a. Pengaruh Kepemimpinan Terhadap Kinerja Pegawai}

Hasil regresi variabel Kepemimpinan diperoleh nilai t sebesar dengan 2,422 dengan signifikansi 0,017 yang menunjukkan lebih kecil dari 0,05. Karena nilai signifikansi pengujian lebih kecil dari $0,05(0,017<0,05)$ maka dapat disimpulkan bahwa ada 
pengaruh yang positif dan signifikan dari variabel Kepemimpinan terhadap Kinerja Pegawai. Hasil penelitian diatas menunjukkan bahwa besarnya tingkat Kepemimpinan pada objek penelitian mempengaruhi Kinerja Pegawai. Oleh karena itu, maka $\mathrm{H}_{1}$ dalam penelitian ini dapat diterima. Dengan kata lain semakin baik tingkat kepemimpinan seorang pemimpin, maka akan semakin tinggi pula kinerja dari para pegawai yang dipimpin.

Hasil penelitian ini sesuai dengan studi terdahulu yang dilakukan oleh Fauzan (2017) yang menyatakan bahwa Kepemimpinan berpengaruh positif dan signifikan terahadap Kinerja Pegawai. Dalam hal ini, pemimpin dapat mempengaruhi perilaku bawahan, agar mau bekerjasama dan bekerja secara produktif untuk mencapai tujuan organisasi. Perilaku dan sifat kepemimpinan akan menjadi pedoman bagi bawahannya, bagaimana seorang pemimpin menjadi teladan bagi bawahannya. Sifat dan perilaku tersebut menjadikan bawahan loyal terhadap organisasi dan sebaliknya.

\section{b. Pengaruh Kompensasi Finansial Terhadap Kinerja Pegawai}

Hasil regresi variabel Kompensasi Finansial diperoleh nilai t sebesar dengan 2,377 dengan signifikansi 0,019 yang menunjukkan lebih kecil dari 0,05. Karena nilai signifikansi pengujian lebih kecil dari $0,05(0,019<0,05)$ maka dapat disimpulkan bahwa ada pengaruh yang positif dan signifikan dari variabel Kompensasi Finansial terhadap Kinerja Pegawai. Hasil penelitian diatas menunjukkan bahwa besarnya tingkat Kompensasi Finansial pada objek penelitian mempengaruhi Kinerja Pegawai. Oleh karena itu, maka $\mathrm{H}_{2}$ dalam penelitian ini dapat diterima. Kantor BKKBN Prov. Jawa Tengah dalam pemberian kompensasi finansial terhadap pegawai yang berupa gaji pokok, bonus, insentif, penghargaan terhadap hasil kerja, asunsansi dan tunjangan-tunjangan, hal ini yang menjadikan suatu motivasi kuat bagi para pegawai dalam melaksanakan suatu pekerjaan dengan maksimal.

Ardi dan Sukmasari (2016) menjelaskan bahwa Pemberian kompensasi berupa finansial merupakan kebutuhan primer, karena finansial yang diterima oleh pegawai dapat menunjang kelangsungan hidupnya, oleh karena itu kebutuhan akan memperoleh kompensasi berupa finansial merupakan faktor pendorong yang kuat bagi pegawai untuk bekerja. Sehingga pemberian kompensasi memiliki hubungan timbal balik, antara pegawai dengan organisasi. Pegawai sangat mengharapkan kompensasi yang diberikan 
dari organisasi sesuai dengan pengorbanan yang dilakukannya, dan organisasi mengharapkan tersedianya pegawai yang cakap dan memenuhi syarat untuk suksesnya tujuan yang telah ditetapkan. Jika organisasi memperhatikan pemberian kompensasi finansial yang mencukupi kepada pegawainya, maka pegawai akan menunjukkan kepuasan kerja yang baik, yang pada akhirnya dapat mencapai tujuan organisasi. Hasil penelitian ini sesuai dengan studi terdahulu yang dilakukan oleh Musyafi' dkk (2016) yang menyatakan bahwa Kompensasi Finansial berpengaruh positif dan signifikan terhadap Kinerja Pegawai.

\section{c. Pengaruh Komitmen Organisasional Terhadap Kinerja Pegawai}

Hasil regresi variabel Komitmen Organisasional diperoleh nilai t sebesar dengan 2,060 dengan signifikansi 0,042 yang menunjukkan lebih kecil dari 0,05. Karena nilai signifikansi pengujian lebih kecil dari $0,05(0,042<0,05)$ maka dapat disimpulkan bahwa ada pengaruh yang positif dan signifikan dari variabel Komitmen Organisasional terhadap Kinerja Pegawai. Hasil penelitian diatas menunjukkan bahwa besarnya tingkat Komitmen Organisasional di objek penelitian mempengaruhi Kinerja Pegawai. Oleh karena itu, maka $\mathrm{H}_{3}$ dalam penelitian ini dapat diterima. Dengan kata lain semakin tinggi tingkat Komitmen Organisasional para pegawai, maka akan semakin tinggi pula tingkat kinerjanya.

Triyaningsih (2014) menjelaskan bahwa komitmen terhadap organisasi artinya lebih dari sekedar keanggotaan formal, karena meliputi sikap menyukai organisasi dan kesediaan untuk mengusahakan tingkat upaya yang lebih tinggi bagi kepentingan organisasinya demi pencapaian tujuan. Berdasarkan definisi ini, dalam komitmen organisasi tercakup unsur loyalitas terhadap organisasi, keterlibatan dalam pekerjaan, dan identifikasi terhadap nilai-nilai dan tujuan organisasi.Selain itu, apabila didalam suatu organisasi mempertimbangkan aspek komitmen organisasional yang tinggi untuk para pegawai, maka akan berpengaruh pada peningkatan kinerja. Hasil penelitian ini konsisten sesuai dengan penelitian yang dilakukan Septiani dkk (2016), yaitu komitmen organisasional berpengaruh positif dan signifikan terhadap kinerja pegawai. 


\section{d. Pengaruh Kepemimpinan Terhadap Disiplin Kerja}

Hasil regresi variabel Kepemimpinan diperoleh nilai t sebesar dengan 5,346 dengan signifikansi 0,000 yang menunjukkan lebih kecil dari 0,05. Karena nilai signifikansi pengujian lebih kecil dari $0,05(0,000<0,05)$ maka dapat disimpulkan bahwa ada pengaruh yang positif dan signifikan dari variabel Kepemimpinan terhadap tingkat Disiplin Kerja. Hasil penelitian diatas menunjukkan bahwa besarnya tingkat Kepemimpinan pada objek penelitian mempengaruhi Disiplin Kerja para pegawai. Oleh karena itu, maka $\mathrm{H}_{4}$ dalam penelitian ini dapat diterima. Dengan kata lain semakin baik tingkat kepemimpinan seorang pemimpin, maka akan semakin tinggi pula tingkat disiplin kerja dari para pegawai yang dipimpin.

Salutondok dan Soegoto (2015) mengungkapkan, organisasi bukan saja mengharapkan pegawai yang mampu, cakap dan terampil, tetapi yang terpenting mereka mau bekerja giat dan berkeinginan untuk mencapai hasil kerja yang maksimal. Kemampuan dan kecakapan pegawai tidak berarti bagi organisasi jika mereka tidak bekerja dengan baik. Selain itu, apabila didalam suatu organisasi mempertimbangkan aspek kepemimpinan yang baik, maka akan berpengaruh pada tingkat disiplin kerja para pegawai. Hasil penelitian ini sesuai dengan penelitian yang dilakukan Nugraheni dkk (2016), yaitu kepemimpinan berpengaruh positif dan signifikan terhadap disiplin kerja pegawai.

\section{e. Pengaruh Kompensasi Finansial Terhadap Disiplin Kerja}

Hasil regresi variabel Kompensasi Finansial diperoleh nilai t sebesar dengan 2,255 dengan signifikansi 0,026 yang menunjukkan lebih kecil dari 0,05. Karena nilai signifikansi pengujian lebih kecil dari $0,05(0,026<0,05)$ maka dapat disimpulkan bahwa ada pengaruh yang positif dan signifikan dari variabel Kompensasi Finansial terhadap Disiplin Kerja. Hasil penelitian regresi tersebut menunjukkan bahwa besarnya tingkat Kompensasi Finansial pada objek penelitian mempengaruhi tingkat Disiplin Kerja dari para pegawai. Oleh karena itu, $\mathrm{H}_{5}$ dalam penelitian ini dapat diterima.

Sunyoto (2012:30) menjelaskan, ketidakpuasan para karyawan/pegawai tehadap kompensasi yang diterima dari organisasi dimana mereka bekerja akan menimbulkan dampak yang tidak baik jika tidak secara cepat diatasi atau diselesaikan. Dampak yang tidak baik itu antara lain karyawan banyak keluhan yang negatif, produktivitas kerja 
menurun, tingkat kemangkiran tinggi, pemogokan kerja dan lain sebagainya. Sehingga pemberian kompensasi berperan penting dengan kaitannya dalam disiplin kerja para karyawan/pegawai. Hasil penelitian ini sesuai dengan studi terdahulu yang dilakukan oleh Nugraheni dkk (2016) yang menyatakan bahwa Kompensasi Finansial berpengaruh positif dan signifikan terhadap Disiplin Kerja.

\section{f. Pengaruh Komitmen Organisasional Terhadap Disiplin Kerja}

Hasil regresi variabel Komitmen Organisasional diperoleh nilai t sebesar dengan 3,079 dengan signifikansi 0,003 yang menunjukkan lebih kecil dari 0,05. Karena nilai signifikansi pengujian lebih kecil dari $0,05(0,003<0,05)$ maka dapat disimpulkan bahwa ada pengaruh yang positif dan signifikan dari variabel Komitmen Organisasional terhadap Disiplin Kerja. Hasil penelitian regresi tersebut menunjukkan bahwa besarnya tingkat Komitmen Organisasional di objek penelitian mempengaruhi tingkat Disiplin Kerja para pegawai. Maka $\mathrm{H}_{6}$ dalam penelitian ini dapat diterima. Dengan kata lain semakin tinggi tingkat Komitmen Organisasional para pegawai, maka akan semakin tinggi pula tingkat disiplin kerja para pegawai tersebut.

Komitmen organisasi mengandung pengertian sebagai suatu hal yang lebih baik dari sekedar kesetiaan yang pasif melainkan menyiratkan hubungan pegawai dengan perusahaan secara aktif. Karena pegawai yang menunjukkan komitmen tinggi memiliki keinginan untuk memberikan tenaga dan tanggung jawab yang lebih dalam menyokong kesejahteraan dan keberhasilan organisasinya. Hasil penelitian ini sesuai dengan studi terdahulu yang dilakukan oleh Ekowati dan Widajanti (2013) yang menyatakan bahwa Komitmen Organisasional berpengaruh positif dan signifikan terhadap Disiplin Kerja.

\section{g. Pengaruh Disiplin Kerja Terhadap Kinerja Pegawai}

Hasil regresi variabel Disiplin Kerja diperoleh nilai t sebesar dengan 2,256 dengan signifikansi 0,026 yang menunjukkan lebih kecil dari 0,05. Karena nilai signifikansi pengujian lebih kecil dari $0,05(0,026<0,05)$ maka dapat disimpulkan bahwa ada pengaruh yang positif dan signifikan dari variabel Disiplin Kerja terhadap Kinerja Pegawai. Hasil penelitian regresi tersebut menunjukkan bahwa besarnya tingkat Disiplin Kerja di objek penelitian mempengaruhi tingkat Kinerja Pegawai. Maka $\mathrm{H}_{7}$ dalam 
penelitian ini dapat diterima. Dengan kata lain semakin tinggi tingkatdisiplin kerja para pegawai, maka akan semakin tinggi pula tingkat kinerja pegawai tersebut.

Shelviana (2015) menjelaskan bahwa disiplin sangat penting untuk pertumbuhan organisasi. Disiplin digunakan terutama untuk memotivasi pegawai agar dapat mendisiplinkan diri. Sebagaimana kemampuan yang dimiliki manusia atau pegawai, namun jika tidak diimbangi dengan pemahaman terhadap disiplin kerja yang tinggi, maka tugas dan pekerjaannya yang dilaksanakan tidak akan menghasilkan kinerja yang baik, bahkan mungkin akan dapat menimbulkan kegagalan dalam tercapainya tujuan dalam organisasi. Karena, disiplin kerja yang baik dan berkualitas merupakan kunci utama keberhasilan suatu organisasi dimana apabila hal tersebut diterapkan dengan baik dan benar maka keinginan dan tujuan suatu organiasi dapat terwujud. Hasil penelitian ini sesuai dengan studi terdahulu yang dilakukan oleh Septiani dkk (2016) yang menyatakan bahwa Disiplin Kerja berpengaruh positif dan signifikan terhadap Kinerja Pegawai.

\section{h. PengaruhKepemimpinan Terhadap Kinerja Pegawai dengan Disiplin Kerja Sebagai Mediasi}

Berdasarkan hasil dari uji Sobel test dapat diketahui bahwa t hitung lebih besar dari $\mathrm{t}$ tabel dengan tingkat signifikansi 0,05 yaitu sebesar 1,6591 $(2,0454>1,6591)$ maka $\mathrm{H}_{08}$ ditolak dan $\mathrm{H}_{\mathrm{a} 8}$ diterima, artinya Kepemimpinan berpengaruh positif dan signifikan terhadap kinerja pegawai dengan disiplin kerja sebagai mediasi. Maka $\mathrm{H}_{8}$ dalam penelitian ini dapat diterima. Dari hasil perbandingan antara pengaruh langsung dan tidak langsung, dimana pengaruh langsung lebih besar yaitu 0,202 daripada pengaruh tidak langsung sebesar 0,087 (0,202 > 0,087). Maka keberadaan disiplin kerja sebagai variabel mediasi hanya memperkecil pengaruh langsung antara Kepemimpinan terhadap Kinerja Pegawai.

Santoso (2013) mengungkapkan bahwa kepemimpinan adalah kemampuan membina dan membimbing dalam menggerakkan dan mengarahkan bawahan kearah pencapaian tujuan organisasi melalui bersifat paksaan atau persuasif, dengan kata lain yaitu kemampuan untuk mempengaruhi (membujuk) orang-orang lain untuk mencapai tujuan dengan antusias dan mengubah sesuatu yang potensial menjadi kenyataan. Kemampuan seorang pemimpin dengan kepemimpinannya harus mampu memberikan 
atau menciptakan disiplin kerja yang lebih tinggi bagi setiap bawahannya agar kinerja dapat lebih tinggi. Hasil penelitian ini sesuai dengan penelitian terdahulu yang dilakukan Santoso (2013), yaitu kepemimpinan berpengaruh positif dan signifikan terhadap kinerja pegawai dengan disiplin kerja sebagai mediasi.

\section{i. PengaruhKomitmen Organisasional Terhadap Kinerja Pegawai dengan Disiplin Kerja Sebagai Mediasi}

Berdasarkan hasil dari uji Sobel test dapat diketahui bahwa t hitung lebih besar dari $\mathrm{t}$ tabel dengan tingkat signifikansi 0,05 yaitu sebesar $1,6591(1,7553>1,6591)$ maka $\mathrm{H}_{09}$ ditolak dan $\mathrm{H}_{\mathrm{a} 9}$ diterima, artinya Komitmen Organisasional berpengaruh positif dan signifikan terhadap kinerja pegawai dengan disiplin kerja sebagai mediasi. Maka $\mathrm{H}_{9}$ dalam penelitian ini dapat diterima. Dari hasil perbandingan antara pengaruh langsung dan tidak langsung, dimana pengaruh langsung lebih besar yaitu 0,180 daripada pengaruh tidak langsung sebesar 0,057 (0,180 > 0,057). Maka keberadaan disiplin kerja sebagai variabel mediasi hanya memperkecil pengaruh langsung antara Komitmen Organisasional terhadap Kinerja Pegawai.

Prihantoro (2012) mengungkapkan bahwa kinerja pegawai dipengaruhi oleh komitmen organisasional. Pegawai yang mempunyai keterlibatan tinggi dalam bekerja tidak mempunyai keinginan untuk keluar dari perusahaan dan dalam hal ini merupakan modal dasar untuk mendorong produktivitas yang tinggi. Hasil penelitian ini sesuai dengan penelitian terdahulu yang dilakukan Nurbiyati dan Wibisono (2014), yaitu komitmen organisasional berpengaruh positif dan signifikan terhadap kinerja pegawai dengan disiplin kerja sebagai mediasi.

\section{Kesimpulan}

1. Kepemimpinan berpengaruh positif dan signifikan terhadap kinerja pegawai.

2. Kompensasi Finansial berpengaruh positif dan signifikan terhadap kinerja pegawai.

3. Komitmen organisasional berpengaruh positif dan signifikan terhadap kinerja pegawai.

4. Kepemimpinan berpengaruh positif dan signifikan terhadap disiplin kerja.

5. Kompensasi finansial berpengaruh positif dan signifikan terhadap disiplin kerja. 
6. Komitmen organisasional berpengaruh positif dan signifikan terhadap disiplin kerja.

7. Disiplin kerja berpengaruh positif dan signifikan terhadap kinerja pegawai.

8. Kepemimpinan berpengaruh positif dan signifikan terhadap kinerja pegawai dengan disiplin kerja sebagai mediasi. Tetapi keberadaan disiplin kerja sebagai variabel mediasi hanya memperkecil pengaruh langsung antara kepemimpinan terhadap kinerja pegawai.

9. Komitmen organisasional berpengaruh positif dan signifikan terhadap kinerja pegawai dengan disiplin kerja sebagai mediasi. Tetapi keberadaan disiplin kerja sebagai variabel mediasi hanya memperkecil pengaruh langsung antara komitmen organisasional terhadap kinerja pegawai.

10. Berdasarkan koefisien determinasi $\left(\operatorname{adj} \mathrm{R}^{2}\right)$ dari variabel dependen kinerja pegawai, dapat diketahui bahwa koefisien determinasi menunjukkan nilai Adjusted $\mathrm{R}^{2}$ sebesar 0,735. Hal ini berarti bahwa variabel kinerja pegawai mampu dijelaskan oleh variabel yang terdiri dari disiplin kerja, kepemimpinan, kompensasi finansial dan komitmen organisasional sebesar $73,5 \%$ sedangkan sisanya $26,5 \%$ dipengaruhi oleh faktor-faktor lain diluar variabel yang diteliti.

11. Berdasarkan koefisien determinasi $\left(\operatorname{adj} \mathrm{R}^{2}\right)$ dari variabel dependen disiplin kerja, dapat diketahui bahwa koefisien determinasi menunjukkan nilai Adjusted $\mathrm{R}^{2}$ sebesar 0,771. Hal ini berarti bahwa variabel disiplin kerja dapat dijelaskan oleh variabel yang terdiri dari kepemimpinan, kompensasi finansial dan komitmen organisasional sebesar $77,1 \%$ sedangkan sisanya $22,9 \%$ dipengaruhi oleh faktor-faktor lain diluar variabel yang diteliti.

\section{Saran}

1. Penelitian selanjutnya dalam mengangkat tema tidak hanya berupa wawancara, juga dapat dikembangkan dengan dokumentasi, studi pustaka atau dengan kuesioner, serta objek diluar penelitian ini.

2. Nilai Adjusted R Square untuk model dalam penelitian ini hanya sebesar $73,5 \%$ dan $77,1 \%$. Berdasarkan hal tersebut, penelitian selanjutnyadiharapkan dapat mempertimbangkan untuk menggunakan variabel lain seperti motivasi, lingkungan kerja, sosialisasi dan budaya organisasi. Supaya lebih sesuai untuk menjelaskan dan memediasi variabel kinerja pegawai. 


\section{DAFTAR PUSTAKA}

Agung, Wahyu (2013), Pengaruh Lingkungan Kerja, Kompensasi, Dan Komitmen Organisasi Terhadap Kepuasan Kerja Karyawan di RS “X”. JRSMI, Vol. 4, No. 1.

Alwi, Syafaruddin (2001), Manajemen Sumber Daya Manusia, Strategi Keunggulan Kompetitif, BPFE UGM, Yogyakarta.

Ardi, Rudi Prasetyo dan Sukmasari, Ninik (2016) Pengaruh Disiplin Kerja, Promosi Jabatan dan Kompensasi Terhadap Kinerja Pegawai pada Dinas Kebudayaan Pariwisata Pemuda dan Olahraga Kabupaten Rembang, Jurnal EBBANK, Vol. 7, No. 2, Hal. 105-110.

Ekowati, Cicilia dan Widajanti, Erni (2013), Pengaruh Keterampilan Pimpinan, Komitmen Organisasi dan Moral Kerja Terhadap Kedisiplinan Pegawai Di Kantor Pelayanan Kekayaan Negara Dan Lelang Surakarta, Jurnal Manajemen Sumberdaya Manusia, Vol. 7, No. 1, Hal. 36-44.

Fahmi, Irham (2016), Pengantar Manajemen Sumber Daya Manusia Konsep dan Kinerja, Jakarta: Mitra Wacana Media.

Fauzan, Muhammad (2017), Pengaruh Stress Dan Kepemimpinan Terhadap Kinerja Perawat Di Rumah Sakit Umum DaerahPematangsiantar, Jurnal Wawasan Manajemen, Vol. 5, No. 1.

Ghozali, Imam (2013). Aplikasi Analisis Multivariate dengan program IBM SPSS 19. Semarang: Badan Penerbit Universitas Diponegoro, Semarang.

Gibson, J.L. (2003),Struktur Organisasi dan Manajemen. Jakarta: Erlangga 5.

Hasibuan S, P, Malayu (2012), Manajemen Sumber Daya Manusia. Edisi Revisi, Jakarta: PT Bumi Aksara.

Mangkunegara, A. A. Anwar Prabu (2013), Manajemen Sumber Daya Manusia, Jakarta: Rineka Cipta.

Moejiono, Imam (2002), Kepemimpinan Dan Keorganisasian, Yogyakarta: UII Press. Musyafi', Roihatul. Utami, Hamidah, Nayati dan Mayowan, Yuniadi (2016), Pengaruh Kompensasi Finansial Dan Non Finansial Terhadap Kinerja Karyawan (Studi pada Karyawan PT PLN (Persero) Area Pelayanan dan Jaringan (APJ) Malang), Jurnal Administrasi Bisnis (JAB), Vol. 39 No. 2.

Nugraheni, Agnes Nana. Leonardo Budi H dan Warso, Mukeri (2016), Pengaruh Kepemimpinan, Kompensasi Finansial Dan Komitmen Terhadap Kedisiplinan Kerja Karyawan Grill On Resto Semarang, Journal Of Management, Vol. 2, No. 2. Nurbiyati, Titik dan Wibisono, Kunto (2014), Analisis Pengaruh Komitmen Afektif, Kontinyu Dan Normatif Terhadap Kinerja Dengan Disiplin Kerja Sebagai Variabel Intervening (pada Balai Besar Kerajinan dan Batik (BBKB) Yogyakarta), Jurnal Kajian Bisnis, Vol. 22, No. 1, hal. 21-37.

Sastrohadiwiryo, Siswanto (2003), Manajemen Tenaga Kerja Indonesia, Pendekatan Administrasi dan Operasional, Jakarta: Bumi Aksara. 
Salutondok, Yohanis dan Soegoto, Agus Supandi (2015), Pengaruh Kepemimpinan, Motivasi, Kondisi Kerja dan Disiplin Terhadap Kinerja Pegawai Di Kantor Sekretariat DPRD Kota Sorong, Jurnal EMBA, Vol. 3, No. 3, Hal. 849-862.

Santoso, Joko (2013), Pengaruh Kepemimpinan Terhadap Kinerja Pegawai Dengan Disiplin Kerja Sebagai Variabel Intervening (Pada Kantor Wilayah Kementerian Agama Provinsi Kalimantan Tengah), Universitas Terbuka Jakarta, TAPM-Dipublikasikan.

Septiani, Maulya. Sunuharyo, Bambang Swasto dan Prasetya, Arik (2016), Pengaruh Komitmen Organisasional Terhadap Disiplin Kerja dan Kinerja Karyawan (Studi Pada Karyawan AJB Bumiputera 1912 Cabang Celaket Malang), Jurnal Administrasi Bisnis (JAB), Vol. 40, No. 2.

Shelviana, Sherly (2015), Hubungan Disiplin Kerja Dengan Kinerja Pegawai Negeri Sipil (PNS) Di Kecamatan Samarinda Ulu Kota Samarinda, eJournal Ilmu Administrasi Negara, Vol. 3, No. 4, Hal. 1912-1926.

Shobirin, Muhamad. Minarsih, Maria M. dan Fathoni, Azis (2016), Analisis Pengaruh Kepemimpinan, Komitmen Organisasi Dan Kepuasan Kerja Terhadap Keinginan Pindah Kerja Karyawan PT. Bank BTPN Mitra Usaha Rakyat Area Semarang1, Journal of Management, Vol. 2, No. 2.

Siagian, S. P. (2002), Kiat Meningkatkan Produktivitas Kerja. Jakarta: Rineka Cipta.

Simamora, Henry (1995), Manajemen Sumber Daya Manusia, Edisi Pertama. Yogyakarta: STIE YKPN

Simamora, Henry (2004),Manajemen Sumber Daya Manusia, Edisi Ketiga. Yogyakarta: STIE YKPN.

Sinungan, Muchdarsyah (1995), Produktivitas Apa dan Bagaimana, Jakarta: Bumi Aksara.

Sunyoto, Danang (2012), Manajemen Sumber Daya Manusia, Cetakan Pertama, Yogyakarta: CAPS (Center for Academic Publishing Service).

Triyaningsih, S, L, (2014), Analisis Pengaruh Disiplin Kerja, Motivasi Kerja Dan Komitmen Organisasi Terhadap Kinerja Karyawan Universitas Slamet Riyadi Surakarta, Informatika, Vol. 1, No. 2. 